\title{
Partial Purification and Properties of Adenosine Triphosphatase (ATPase) from Liver Fluke Fasciola hepatica
}

\author{
Karaciğer Kelebeği Fasciola hepatica' dan Adenozin trifosfataz (ATPaz)’ in Kismi \\ Saflaştırılması ve Özellikleri
}

\author{
Husain Hassan¹, Ali Abeer² \\ 'Department of Biology, Kirkuk College of Science, Iraq \\ 2Department of Community Health, Technical Institute of Kirkuk, Kirkuk, Iraq
}

\section{ABSTRACT}

Objective: The adenosine triphosphatase (ATP phosphohydrolase, EC 3.6.1.3.;ATPase) is a membrane -bound enzyme which transport protons across the plasma membrane using ATP as an energy source.

Methods: The adenosine triphosphatase (ATPase ; EC: 3.6.1.3) was extracted from membrane preparations of adult Fasciola hepatica by chloroform treatment and purified by means of ammonium sulphate fractionation, gel filtration on sephadex G-200 and DEAE- Cellulose chromatography.

Results: The molecular weight was calculated to be 305.000 dalton by gel filtration. Kinetic experiments demonstrated a biphasic linear lineweaver - burk relationship ( $\mathrm{km}=0.142$ and $1.66 \mathrm{mM}$ ) thus revealing the existence of two substrate binding enzyme sites.

Conclusion: In our study revealed that partial inhibition of $\mathrm{Mg}^{2+}$ dependent purified enzyme by oligomycin suggest the absence of mitochondrial ATPase in F. hepatica. (Turkiye Parazitol Derg 2014; 38: 26-31)

Key Words: ATPase, Fasciola hepatica, gel filtration on sephadex G-200, DEAE- Cellulose chromatography Received: 25.06.2013

Accepted: 12.11.2013

\section{ÖZET}

Amaç: Adenozin trifosfataz (ATP fosfohidrolaz, EC 3.6.1.3, ATPaz) enerji kaynağı olarak ATP kullanarak plazma membranında proton taşıyan bir membran-bağlı enzimdir.

Yöntemler: Adenozin trifosfataz (ATPaz; EC: 3.6.1.3) yetişkin Fasciola hepatica'nın membran preparatlarından kloroform ile muamele edilerek ekstrakte edildi ve amonyum sülfat fraksiyonasyonu, sefadeks G-200 jel filtrasyonu ve DEAE-Selüloz kromatografisi vasıtasıyla saflaştırıldı.

Bulgular: Moleküler ağırlığı, jel filtrasyon ile 305000 dalton olarak hesaplandı. Kinetik deneyler, iki fazlı, doğrusal bir Lineweaver-Burk ilişkisini ortaya koydu (km=0.142 ve $1.66 \mathrm{mM})$, böylece subtrat bağlayan iki enzim bölgesinin varlığı gösterildi.

Sonuç: Çalışmamız ortaya koymuştur ki; oligomisin tarafından $\mathrm{Mg}^{2+}$ bağımlı saflaştırılmış enzimin kısmi inhibisyonu F. hepatica'da mitokondriyal ATPaz bulunmadığını düşündürmektedir. (Turkiye Parazitol Derg 2014; 38: 26-31)

Anahtar Sözcükler: ATPaz, Fasciola hepatica, Sefadeks G-200 jel filtrasyonu, DEAE-Selüloz kromatografisi

Geliş Tarihi: 25.06.2013

Kabul Tarihi: 12.11.2013

Address for Correspondence / Yazışma Adresi: Dr. Husain Hassan, Department of Biology, College of Science, Kirkuk, Iraq. Phone: 009647701324894 E-mail: hussainfadel86@yahoo.com DOI:10.5152/tpd.2014.3251

CCopyright 2014 Turkish Society for Parasitology - Available online at www.tparazitolderg.org

CTelif hakkı 2014 Türkiye Parazitoloji Derneği - Makale metnine www.tparazitolderg.org web sayfasından ulaşılabilir. 


\section{INTRODUCTION}

Fasciola hepatica is the species of parasitic flatworms that infects the liver of various mammals, including humans. The disease caused by the organism is called Fascioliasis or Fasciolosis. It is a parasitic flatworm of the class Trematoda, phylum Platyhelminthes that causes great economic losses in sheep and cattle.

The adenosine triphosphatase (ATP phosphohydrolase, EC 3.6.1.3.; ATPase) is a membrane -bound enzyme which transport protons across the plasma membrane using ATP as an energy source (1-4). It also plays a crucial role in oxidative phosphorylation upon the formation of ATP in biological membrane containing respiratory apparatus. Cell membrane ecto- ATPases are integral membrane glycoproteins that are millimolar divalent cation-dependent, low specificity enzymes that hydrolyze all nucleoside triphosphates. Their physiological role is still unknown. However, several hypotheses have been suggested such as; (i) protection from cytolytic effects of extracellular ATP, (ii) regulation of ectokinase substrate concentration, (iii) termination of purinergic signaling, (iv) involvement in signal transduction, and $(v)$ involvement in cellular adhesion.

In contrasts to the large amount of information available about mitochondrial ATPase in mammals $(5-8)$, bacteria $(9,10)$ and parasitic protozoa (11-15), little is known about this enzyme in parasitic helminthes. We have therefore report here the purification and properties of the ATPase from adult Fasciola hepatica.

\section{METHODS}

Organism: Adult Fasciola hepatica was collected from the bile duct of cattle freshly slaughtered at the local abattoir in Kirkuk and washed clean of host's tissue in normal saline.

Preparation of Crude Extract and Cellular Fractionation: All procedures were performed at $4^{\circ} \mathrm{C}$. Crude homogenates of worms $(1 \mathrm{gm})$ were obtained as described previously after homogenized in a Potter-Elvehjem homogenizer (6) with 2 vols. of ice cold $50 \mathrm{mM}$ Tris- $\mathrm{HCl}(\mathrm{pH} 7.2)$ containing $0.25 \mathrm{M}$ sucrose and $0.1 \mathrm{mM}$ dithiothritol (TSD buffer). After centrifugation for $1 \mathrm{hr}$. at $105000 \mathrm{~g}$ at $4^{\circ} \mathrm{C}$, the material sediment was removed, resuspended in TDS buffer and used to investigate the subcellular localization of the enzyme. The adult worms were grounded in a chilled mortar with TSD buffer containing $0.2 \%$ Triton $\mathrm{x}-100$ and subjected to differential centrifugation as previously described (16), yielding particle fraction P1 (2100g for $10 \mathrm{~min}$.), P2 (15800g for 10min.) and P3 (240000 for $1 \mathrm{hr}$.). The four fractions produced were frozen and thawed three times to disrupt organelles, and were assayed for enzyme activity.

\section{Partial purification of the ATPase:}

1. Disruption of organisms: The worm was washed with $50 \mathrm{mM}$ Tris- $\mathrm{HCl}$ (pH7.6) containing $0.25 \mathrm{M}$ sucrose , $2.5 \mathrm{mM}$ magnesium chloride and $2 \%$ bovine serum albumin (TSMA buffer) then suspended in the minimum volume of cold buffer, mixed with glass beads (75-150 $\mu \mathrm{M}$ dia.; $2 \mathrm{~g}$ per $\mathrm{g}$ of worms wet wt.)and disrupted by grinding in a chilled mortar for $5 \mathrm{~min}$. at $4^{\circ} \mathrm{C}$ as described by Frasch et al. (17), 1978. The homogenate was rapidly diluted with cold TSMA buffer and centrifuged at $800 \mathrm{~g}$ at $4^{\circ} \mathrm{C}$ for $5 \mathrm{~min}$. to remove the unbroken cells and glass beads. The homogenate was then centrifuged at $4500 \mathrm{~g}$ at $4^{\circ} \mathrm{C}$ for $10 \mathrm{~min}$. The pellet was washed thrice and resuspended in TSMA buffer and used as membrane bound ATPase and as source for the solublilisation of the enzyme.

2. Chloroform extraction was performed as described by (18). The chloroform (2 vol.) was added to the particles suspended in TSMA buffer, thoroughly mixed and the precipitate protein eliminated by centrifugation for $2 \mathrm{~min}$. at 500x $\mathrm{g}$ at room temperature. The supernatant was centrifuged at 114000xg for $60 \mathrm{~min}$. at $10^{\circ} \mathrm{C}$. The supernatant containing the solubilized ATPase was used for the purification of the enzyme.

3. Ammonium sulphat fractionation: The protein in the supernatant of the chloroform treatment was brought to $70 \%$ saturation by the slow addition of $\left(\mathrm{NH}_{4}\right)_{2} \mathrm{SO}_{2}$ and after $10 \mathrm{~min}$., the suspension was centrifuged at $27000 \times \mathrm{g}$ for $15 \mathrm{~min}$. The precipitate was dissolved in $10 \mathrm{mM}$ Tris- $\mathrm{HCl}(\mathrm{pH} 7.6)$ containing $1.0 \mathrm{mM}$ EDTA (TE buffer)

4. Gel filtration on Sephadex G-200: The protein solution obtained above was applied to a column $(1.6 \times 34 \mathrm{~cm})$ of sephadex G-200 previously equilibrated with TE buffer and the elution was accomplished with the same buffer at a flow rate of $8 \mathrm{ml} / \mathrm{hr}$. Fractions of $4 \mathrm{ml}$ were collected.

5. Column chromatography on DEAE- Cellulose: The active fractions from the sephadex G- 200 column were pooled and applied to a column $(1.3 \times 45 \mathrm{~cm})$ of DEAE- cellulose equilibrate with the same TE buffer and elution was preformed with TE buffer containing $10,20,25, \mathrm{mM} \mathrm{KCl}$. The active fractions were pooled, concentrated by precipitation with ammonium sulphate at $70 \%$ saturation and used for the experiments described.

6. Molecular weight determination: Enzyme molecular weight was estimated by gel filtration on sephadex G-200 (column $1.6 \times 34 \mathrm{~cm}$ ) equilibrated in TE buffer(19), using Ovalbumin (43000), bovine serum albumin (67000), lactate dehydrogenase (140000), catalase (248000), Ferritin (440000) as protein markers, under experimental conditions similar to those of the Sephadex step of the purification procedure. The void volume of the column was determined with Blue Dextran 2000

Enzyme assay: ATPase activity was conducted at $37^{\circ} \mathrm{C}$ in a $1 \mathrm{~mL}$ reaction volume of $50 \mathrm{mM}$ Tris- $\mathrm{HCl}$ buffer $(\mathrm{pH} 7.2), 1.0 \mathrm{mM} \mathrm{MgCl}_{2}$ $1.0 \mathrm{mM}$ ATP, and sufficient enzyme to yield an appropriate reaction rate. Assays were terminated after $30 \mathrm{~min}$. by the addition of $1 \mathrm{~mL}$ of trichloro acetic acid $10 \%(\mathrm{w} / \mathrm{v})$ and the resulting mixture was centrifuged at $2000 \mathrm{~g}$ for $10 \mathrm{~min}$. at $4^{\circ} \mathrm{C}$. Liberated inorganic phosphate $(\mathrm{Pi})$ was determined by the method of Fisk and Subbarow (20). One unit of ATPase activity is defined as the amount of enzyme which hydrolyses $1.0 \mu \mathrm{mol}$ of ATPase per min. per mg protein

Protein determination: Protein concentration were estimated by the method of Lowery et al. (21) with bovine serum albumin as standard.

Statistical Analysis: All data expressed as mean from triplicate experiments. 


\section{RESULTS}

The activity of ATPase recovered in the various cell fractions of $F$. hepatica is shown in the Tables 1 and 2. ATPase was recovered in all fractions but the highest amount were in fractions $P_{1}, P_{2}$ and $P_{3}$. By the same procedure, succinate dehydrogenase which is known to be a particulate enzyme was recovered exclusively in the pellet fraction. It was concluded that the ATPase is particulate enzyme.

The purification of ATPase from F. hepatica is summarized in Table 3.

The yield of the chloroform extraction was consistently higher than 100\%; this might be due to some latency of the ATPase activity in the particles. The solubilized enzyme by precipitation with ammonium sulphate was found to be efficient to eliminate the fat and contaminating proteins. Although precipitation with ammonium sulphate made it possible to concentrate the solubilized enzyme into a small volume with no effect on the enzyme specific activity. The enzyme was further purified with Sephadex G-200 and DEAE-Cellulose to eliminate the trace amount of contaminated protein. It has been shown that about $55 \%$ of the solubilized enzyme was recovered after gel filtration on Sephadex G-200 and about $84 \%$ of this fraction were eluted from DEAE-

Table 1. Cellular fractionation of ATPase from Fasciola hepatica

\begin{tabular}{|l|c|c|c|l|}
\hline Fractions & $\begin{array}{c}\text { Total } \\
\text { Volume }(\mathrm{mL})\end{array}$ & $\begin{array}{c}\text { Specific activity } \\
\mu \mathrm{mol} / \mathrm{min} / \mathbf{m g} \\
\text { protein }\end{array}$ & $\begin{array}{c}\text { Total } \\
\text { activity }\end{array}$ & $\begin{array}{l}\text { Activity } \\
\%\end{array}$ \\
\hline $\begin{array}{l}\text { Crude } \\
\text { homogenate }\end{array}$ & 20 & 0.810 & 649 & \\
\hline Pellet $(\mathrm{p})$ & 17 & 0,567 & 386 & 60 \\
\hline Supernatant & 15 & 0.435 & 261 & 40 \\
\hline
\end{tabular}

Table 2. Distribution of ATPase in subcellular fractions of Fasciola hepatica

\begin{tabular}{|l|c|c|c|c|}
\hline Fractions & $\begin{array}{c}\text { Total } \\
\text { volume }(\mathrm{mL})\end{array}$ & Activity* & $\begin{array}{c}\text { Total } \\
\text { activity }\end{array}$ & $\begin{array}{c}\% \text { Recovered } \\
\text { activity }\end{array}$ \\
\hline $\begin{array}{l}\text { Crude } \\
\text { homogenate }\end{array}$ & 10 & 1.90 & 760 & \\
\hline Pellet (p1) & 8 & 1.16 & 371.26 & 27 \\
\hline Pellet (p2) & 7 & 1.27 & 355.6 & 26 \\
\hline Pellet (p3) & 6 & 1.30 & 364 & 27 \\
\hline Supernatant & 6 & 0.10 & 364 & 20 \\
\hline $\begin{array}{l}\star \\
\text { The activities given are in } \mu \mathrm{mol} \text { of inorganic phosphate liberated from } \\
\text { hydrolysis of ATP }\end{array}$
\end{tabular}

Cellulose column chromatography by $\mathrm{KCl}$. The enzyme was purified by a factor of 112 with specific activity of $107 \mu \mathrm{mol} / \mathrm{min}$./ $\mathrm{mg}$ protein. The molecular weight of the native enzyme determined by gel filtration on Sephadex G-200 was about 305000 dalton (Figure 1).

Preliminary assay of ATPase was conducted to ensure that the reaction rate (liberation of inorganic phosphate) was a linear function of assay time and protein concentration in the assay mixture; under such conditions these reaction rates should provide a reasonable estimate of initial reaction velocities.

The $\mathrm{pH}$ optimum of ATPase activity was between (7.5-9.0) and further ATPase assays were conducted at this $\mathrm{pH}$. Under these assay conditions, the ATPase activity displayed a biphasic double reciprocal plot which allowed the calculation of two different $\mathrm{Km}$ values, namely 0.142 and $1.66 \mathrm{mM}$ (Figure 2).

In the absence of divalent cations the purified ATPase displayed significant activity. The ATPase activity was inhibited nearly $100 \%$ when EDTA was added to the assay mixture (Table 4). The inhibition of ATPase activity by EDTA might be due to the presence of endogenous divalent cations in the crude homogenate or due to contamination of assay mixture with divalent cations from an unbroken source. It is evident (Table 4) that the ATPase activity was neither inhibited nor stimulated by the addition of $\mathrm{Na}^{+}$and $\mathrm{K}^{+}\left(\mathrm{Na}^{+} / \mathrm{K}^{+}\right.$ratio $\left.5 / 1\right)$ to the assay mixture. Also, in the presence and absence of $\mathrm{Na}^{+} / \mathrm{K}^{+}$the ATPase activity was not inhibited by $1 \mathrm{Mm}$ Ouabin (Table 4).

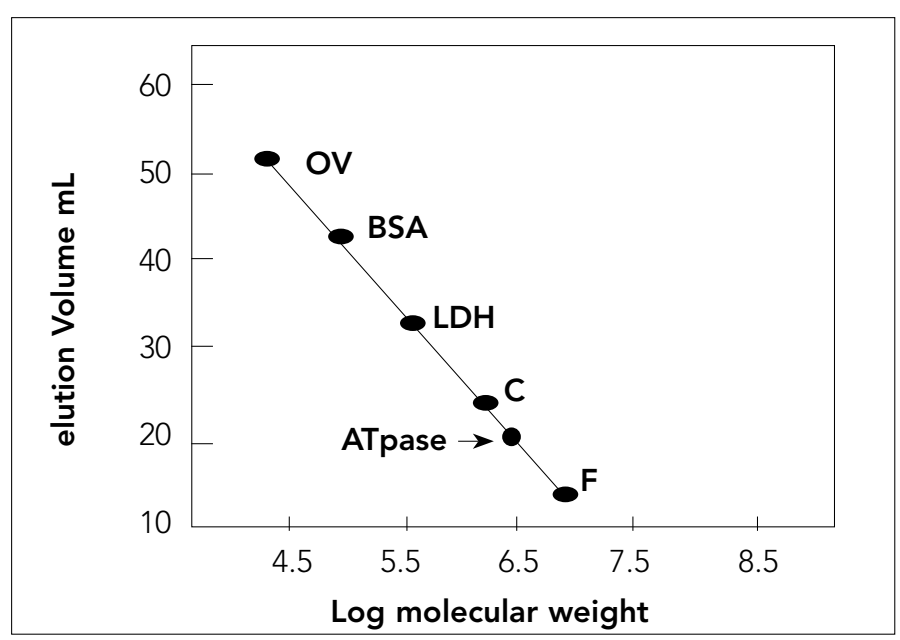

Figure 1. Estimation of the molecular weight of ATPase by gel filtration on Sephadex G-200. Standard proteins F=Ferritin; $B S A=$ Bovine Serum albumi; $O V=$ Ovalbumin; $C=$ Catalase; $L D H=$ Lactate dehydrogenase. The elution volume determined by Blu dextran 2000

Table 3. Purification of the ATPase from Fasciola hepatica

\begin{tabular}{|c|c|c|c|c|c|}
\hline Step & $\begin{array}{c}\text { Total } \\
\text { protein }(\mathrm{mg})\end{array}$ & $\begin{array}{l}\text { Total activity } \\
\mu \mathrm{mol} / \mathrm{min}\end{array}$ & $\begin{array}{c}\text { Specific activity } \\
\mu \mathrm{mol} / \mathrm{min} . / \mathrm{mg} \text { protein }\end{array}$ & $\begin{array}{l}\text { Purification } \\
\text { fold }\end{array}$ & Yield \% \\
\hline $800-4500 x$ & 23700 & 22.6 & 0.953 & 1 & 100 \\
\hline Chloroform extraction & 13600 & 30.8 & 2260 & 2.30 & 136 \\
\hline Ammonium sulphate precipitation & 10400 & 28.6 & 2750 & 2.80 & 127 \\
\hline Sephadex G-200 & 0.203 & 15.7 & 77300 & 81.10 & 69 \\
\hline DEAE-cellulose chromatography & 0.123 & 13.1 & 106500 & 111.3 & 58 \\
\hline
\end{tabular}




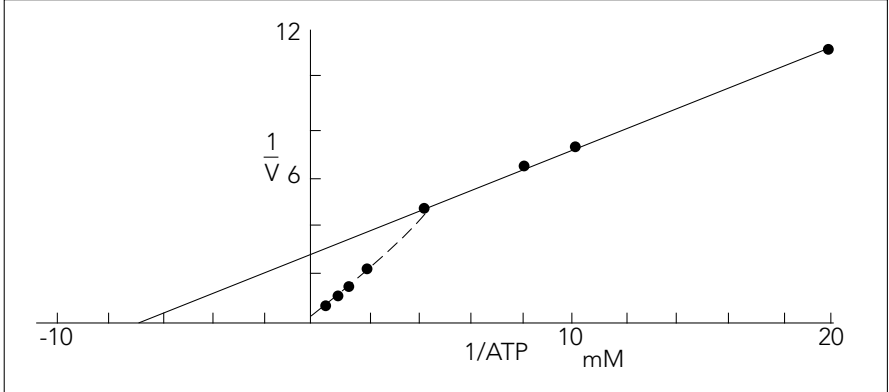

Figure 2. Lineweaver-Burke plot of the effect of substrate concentration (ATP) on purified ATPase. The reaction mixture contains Tris- $\mathrm{HCl} 50$ mM, pH8.0, Mg Cl2 5 mM, ATP(0.05-20) mM

Table 4. The effects of various potential effectors on ATPase activity of Fasciola hepatica

\begin{tabular}{|c|c|c|}
\hline & Assay mixture & ATPase Activity* \\
\hline 1. & Exract +1mMATP & 48 \\
\hline 2. & + $2.5 \mathrm{~m} \mathrm{M}$ EDTA & 0.9 \\
\hline 3. & $+\mathrm{Mg}^{+2}$ & 163.2 \\
\hline 4. & $+\mathrm{Ca}^{+2}$ & 87.7 \\
\hline 5. & $+\mathrm{Mn}^{+2}$ & 120.4 \\
\hline 6. & $+\mathrm{Ca}^{+2}, \mathrm{Mg}^{+2}$ & 163.6 \\
\hline 7. & $\mathrm{Mg}^{+2}, \mathrm{Mn}^{+2}+$ & 109.5 \\
\hline 8. & $+\mathrm{Ca}^{+2}, \mathrm{Mn}^{+2}$ & 131.3 \\
\hline 9. & $+50 \mathrm{mM} \mathrm{Na}^{+}+10 \mathrm{mM} \mathrm{K}^{+}$ & 48.1 \\
\hline 10. & $+50 \mathrm{mM} \mathrm{Na}^{+}+10 \mathrm{mM} \mathrm{K}^{+}$ & 48 \\
\hline 11. & $\begin{array}{l}+50 \mathrm{mM} \mathrm{Na}^{+}+10 \mathrm{mM} \mathrm{K}^{+}+1 \mathrm{mM} \\
\text { ouabain }\end{array}$ & 48.2 \\
\hline 12. & $+\mathrm{Mg}^{+2}+10 \mathrm{mM}$ fluorid & 159.4 \\
\hline 13. & $+\mathrm{Mg}^{+2}+10 \mathrm{mM}$ Molybdate & 38.2 \\
\hline \multicolumn{3}{|c|}{$\begin{array}{l}\text { *The activities given are in } \mu \mathrm{mol} \text { of inorganic phosphate liberated from } \\
\text { hydrolysis of ATP, and values represent the mean of triplicate } \\
\text { determinations using a single purified enzyme }\end{array}$} \\
\hline
\end{tabular}

Despite the significant ATPase activity in the absence of divalent cations, the addition of $\mathrm{Mg}^{2+}, \mathrm{Mn}^{2+}$ or $\mathrm{Ca}^{2+}$ to the assay mixture activated the ATPase activity of F. hepatica (Figure 3). At low concentrations, all three divalent cations, increased ATPase activity with $\mathrm{Mg}^{2+}$ being the most effective activator.

On the other hand, at higher concentrations $(>10 \mathrm{mM}) \mathrm{Mg}^{2+}$ and $\mathrm{Mn}^{2+}$ were inhibitory while $\mathrm{Ca}^{2+}$ resulted in steady increasing ATPase activity (Figure 3). As shown in (Table 4), ammonium molybdate was found to be effective inhibitor of ATPase activity while sodium fluoride did not. Figure 4 shows the inhibition of ATPase activity by the antibiotic oligomycin. The maximum inhibition was about $53 \%$.

\section{DISCUSSION}

The present investigation has shown that in several respects the ATPase of $F$.hepatica appear to be similar to those of parasitic protozoa $(1,2,4,11)$ and parasitic helminthes $(15,22,23)$. The recovery of a significant proportion of ATPase activity in the particulate fractions suggest that this enzyme may be associated with

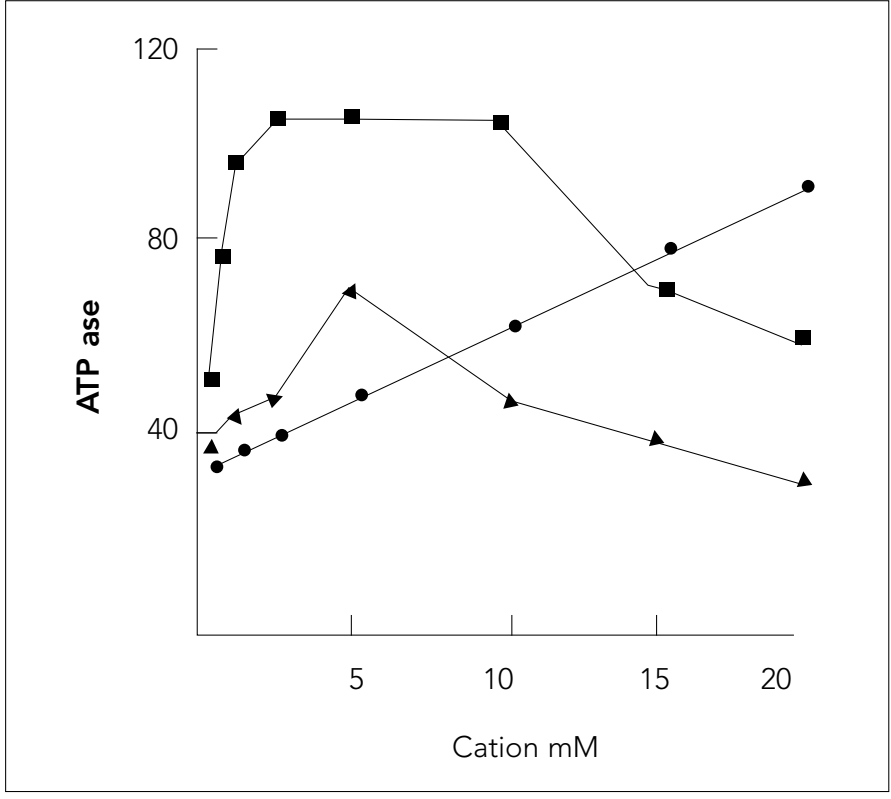

Figure 3. Effect of divalent cations on ATPase activity in Fasciola hepatica

Reaction mixture contains Tris- $\mathrm{HCl} 50 \mathrm{mM}$, pH8.0, ATP $1 \mathrm{mM}$, and divalent cations (0.1-20) $\mathrm{mM} \mathrm{Mg}^{2+}(\mathbf{\square}), \mathrm{Ca}^{2+}(\mathbf{O}), \mathrm{Mn}^{2+}$

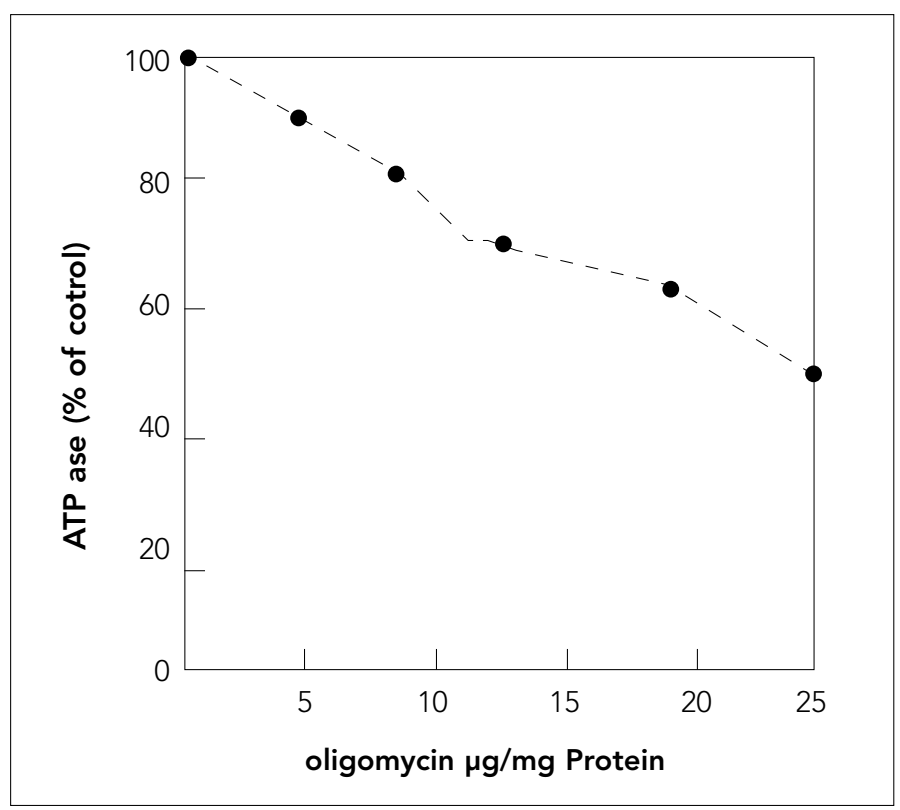

Figure 4. Inhibition of ATPase by Oligomycin in Fasciola hepatica

tegument as has been reported in the tapeworm Hymenolepis dimiuta (22). The ATPase of $F$. hepatica appear to function in the hydrolysis of nucleotide and the resultant nucleotide could be further catabolized by the surface located $5 \$$ - nucleatidase (unpublished data) to yield nucleotides, which could be taken into the cells more easily and so it is possible that the ATPase may play a part in the interaction of the parasite with its host.

The specific activity of purified ATPase in this investigation was considerably higher than most ATPase attained values available from other parasite such as Trypanosoma cruzi; Crithidia fasiculata $(2,24)$. The molecular weight of ATPase from $F$. hepatica are 
shown to be fairly consistent with those reported for other ATPase, among them the enzymes from $T$. cruzi ${ }^{2}$ and C. fasiculata (24). The calculation of the different $\mathrm{Km}$ value for purified $F$. hepatica are very similar to those reported for the purified $T$. cruzi enzyme (25). The activity of F. hepatica ATPase is activated by cations and results showed that the effect of these cations( $\mathrm{Ca}^{2+}, \mathrm{Mn}^{2+}, \mathrm{Mg}^{2+}$ ) are not additive, thus indicating the presence of single enzyme rather than there being multiple enzymes each specific for a single divalent cation.

Comparison of the ATPase activity reported in this study with that of other animal cell membranes indicates that the ATPase in the $F$. hepatica dose not resemble the more intensively studied ATPases. The ouabain insensitivity of the enzyme (in the absence or present of added $\mathrm{Na}^{+}$and $\mathrm{K}^{+}$) in the F. hepatica suggest that it is not due to $\mathrm{Na}^{+}-\mathrm{K}^{+}$activated ATPase. In contrast, the existence of two $\left(\mathrm{Na}^{+}, \mathrm{K}^{+}\right)$ATPase isoforms has been reported in the related trematode Scistosoma mansoni(26). The absence of $\mathrm{Ca}^{2+}$ activation also indicate the absence of $\mathrm{Ca}^{2+}$ transport function usually associated with the $\mathrm{Ca}^{2+}$ activated, $\mathrm{Mg}^{2+}$-dependent ATPase(23). Unlike mitochondria $\mathrm{Mg}^{2+-}$ ATPase (24) the ATPase of F. hepatica was only partially sensitive to oligomycin at high inhibitor concentrations. The small inhibition by oligomycin may be due to contamination of membrane fraction with mitochondria and so it is possible to suggest that the origin of the major portion of ATPase activity in this was not mitochondrial. The result of this study firmly provided the first direct evidence for the existence of $\mathrm{Mg}^{2+}$ - dependent ATPase in F. hepatica, a fact which is of great interest from the phylogenetic point of view.

\section{CONCLUSION}

In our study revealed that partial inhibition of $\mathrm{Mg}^{2+}$ dependent purified enzyme by oligomycin suggest the absence of mitochondrial ATPase in F. hepatica.

\section{Ethics Committee Approval: N/A}

\section{Informed Consent: N/A}

Peer-review: Externally peer-reviewed.

Author Contributions: Concept - H.H., A.A.; Design - H.H., A.A.; Supervision - H.H.; Funding - H.H., A.A.; Materials - H.H., A.A.; Data Collection and/or Processing - A.A.; Analysis and/or Interpretation - H.H., A.A.; Literature Review - H.H., A.A.; Writing - H.H., A.A.; Critical Review - H.H., A.A.

Conflict of Interest: No conflict of interest was declared by the authors.

Financial Disclosure: The authors declared that this study has received no financial support.

Etik Komite Onayı: Gerek yoktur.

Hasta Onamı: Gerek yoktur.

Hakem değerlendirmesi: Dış bağımsız.

Yazar Katkıları: Fikir - H.H., A.A.; Tasarım - H.H., A.A.; Denetleme
- H.H.; Kaynaklar - H.H., A.A.; Malzemeler - H.H., A.A.; Veri toplanması ve/veya işlemesi - A.A.; Analiz ve/veya yorum - H.H., A.A.; Literatür taraması - H.H., A.A.; Yazıyı yazan - H.H., A.A.; Eleştirel Inceleme - H.H., A.A.

Çıkar Çatışması: Yazarlar herhangi bir çıkar çatışması bildirmemişlerdir.

Finansal Destek: Yazarlar bu çalışma için finansal destek almadıklarını beyan etmişlerdir

\section{REFERENCES}

1. Jesus JB, Lopes AHCS, Meyer-Fernandes JR. Characterization of an ecto-ATPase of Tritrichomonas foetus. Vet Parasitol 2002; 103: 29-42. [CrossRef]

2. Meyer-Fernandes JR, Saad-Nehme J, Peres-Sampaio CE, BelmontFirpo R, Bisaggio DF, Do Couto LC, et al. A Mg-dependent ecto-ATPase is increased in the infective stages of Trypanosoma cruzi. Parasitol Res 2004; 93: 41-50. [CrossRef]

3. Cortes VF, Veiga-Lopes FE, Barrabin H, Alves-Ferreira M, Fontes CF. The gamma subunit of $\mathrm{Na}+, \mathrm{K}+-$ ATPase: role on ATPase activity and regulatory phosphorylation by PKA. Int J Biochem Cell Biol 2006; 38: 1901-13. [CrossRef]

4. Borges FP, Gottardi B, Stuepp C, Larré AB, Tasca T, De Carli GA, et al. Characterization of an ecto-5'-nucleotidase (EC 3.1.3.5) activity in intact trophozoites of Trichomonas gallinae. Vet Parasitol 2007; 143: 106-11. [CrossRef]

5. Glynn I. The Na+, K+. transporting adenosine triphosphates. Martonosi, AN, editor. The enzymes of biological membranes. Volume 3: Membrane Transport. New York: Springer; 1989. p. 28-114.

6. Robinson JD. Modification of ligand to the $\mathrm{Na}+/ \mathrm{K}+$-activated ATPase. Biochem Biophs Acta 1989; 997: 41-8. [CrossRef]

7. Kurihara K, Hosoi K, Kodama A, Ueha T. A new elecrophoraretic variant of subunit of $\mathrm{Na}+/ \mathrm{K}+$-ATPase from the submandibular gland of rats. Biochem Biophs Acta 1990; 1039: 234-41. [CrossRef]

8. Ohkohchi N, Shibuya H, Seya K, Satomi S, Taguchi Y, Mori S. New evaluation method for viability of mitochondria in liver graft using fluorescent dye. Transplantation Proceedings. 1993; 25: 3210-2.

9. Cook GM, Keis S, Morgan HW, von Ballmoos C, Matthey U, Kaim G, et al. Purification and Biochemical Characterization of the F1Fo-ATP Synthase from Thermoalkaliphilic Bacillus sp. Strain TA2.A1. J Bacteriol 2003; 185: 4442-9. [CrossRef]

10. Sun Y, Fukamachi T, Saito H, Kobayashi H. ATP requirement for acidic resistance in escherichia coli. J Bacteriol 2011; 193: 3072-7. [CrossRef]

11. Meyer-Fernandes JR. Ecto-ATPases in protozoa parasites: looking for a function. Parasitol Inter. 2002; 51: 299-303. [CrossRef]

12. Meyer-Fernandes JR, Saad-Nehme J, Peres-Sampaio CE, BelmontFirpo R, Bisaggio DF, Do Couto LC, et al. A Mg-dependent ecto-ATPase is increased in the infective stages of Trypanosoma cruzi. Parasitol Res 2004; 93: 41-50. [CrossRef]

13. Elandalloussi LM, Adams B, Smith PJ. ATPase activity of purified plasma membranes and digestive vacuoles from Plasmodium falciparum. Mol Biochem Parasitol 2005; 141: 49-56. [CrossRef]

14. de Sá Pinheiro AA, Cosentino-Gomes D, Lanfredi-Rangel A, Ferraro RB, De Souza W, Meyer-Fernandes JR. Giardia lamblia: Biochemical characterization of an ecto-ATPase activity. Exp Parasitol 2008; 119: 279-84. [CrossRef]

15. Moore CM, Hoey EM, Trudgett A, Timson DJ. A plasma membrane Ca2+ -ATPase (PMCA) from the liver fluke, Fasciola hepatica. Int $J$ Parasitol 2012; 42: 851-8. [CrossRef]

16. Skou JC. The identification of the sodium-pump as the membrane-bound $\mathrm{Na}+/ \mathrm{K}+$-ATPase: a commentary on 'The Influence of Some Cations on an Adenosine Triphosphatase from Peripheral Nerves'. Biochem Biophs Acta 1980; 1000: 435-8. [CrossRef]

17. Frasch AC, Cazzulo JJ, Stoppani AO. Solubilization and some properties of the Mg2+-activated adenosine triphosphatase from Trypanosoma cruzi. Comp Biochem Physiol 1978; 618: 207-12. 
18. Stryer L. Biochemistry. San Francisco: W.H. Freeman and company; 1982.

19. Vieira L, Slotki I, Cabantchik Zl. Chloride Conductive Pathways Which Support Electrogenic H+ Pumping by Leishmania major Promastigotes . J Biol Chem 1995; 270: 5299-304. [CrossRef]

20. Fisk C, Sabbaraw Y. The colorimetric determination of phosphorous. J Biol Chem 1925; 66: 3254-400.

21. Lowry OH, Rosebrough NJ, Farr AL, Randall RJ. Protein measurement with the folin phenol reagent. J Biol Chem 1951; 193: 265-75.

22. Wani HJ, Srivastava VML. Ca2+/Mg2+ -dependent ATPase activity in Hymenolepis diminuta mitochondria. Vet Parasitol 1995; 58: 17-26. [CrossRef]

23. Cunha VMN, Reis JMA, Noël F. Evidence for the presence of two (Ca2+-Mg2+) ATPases with different sensitivities to thapsigargin and cyclopiazonic acid in the human flatworm Schistosoma mansoni. Comp Biochem Physiol B 1996; 114: 199-205. [CrossRef]

24. Higa IA, Cazzulo JJ. Mg2+-Activated adenosine triphosphatase from Crithidia fasciculata: Purification and inhibition by suramin and efrapeptin. Mol and Bioch Parasitol 1981; 3: 357-67. [CrossRef]

25. Cataldi de Flombaum MA, Stoppani AO. High-affinity calcium-stimulated, magnesium-dependent adenosine triphosphatase in Trypanosoma cruzi. Comp Biochem Physiol B 1992; 103: 933-7. [CrossRef]

26. Noël F, Soares de Moura R. Schistosoma mansoni: Preparation, characterization of $(\mathrm{Na}++\mathrm{K}+$ ) ATPase from tegument and carcass. Experimental Parasitol 1986; 62: 298-307. [CrossRef] 